\title{
Accura balloon tamponade to successfully treat right common iliac vein perforation - an unconventional use
}

\author{
Tamponada przy użyciu balonu Accura w celu skutecznego leczenia perforacji \\ żyły biodrowej wspólnej prawej - niekonwencjonalne zastosowanie
}

\author{
Santosh Kumar Sinha, Ramesh Thakur, Mukesh Jitendra Jha, Amit Goel, Mohit Sachan, \\ Vikas Mishra, Ashutosh Kumar \\ Department of Cardiology, LPS Institute of Cardiology, G.S.V.M. Medical College, Kanpur, India
}

\begin{abstract}
Percutaneous mitral valvotomy is effective alternative for management of patients with symptomatic mitral stenosis in pregnant women. Gravid uterus may compress and distort inferior vena cava. Patients will have their abdomen shielded with lead sheets to limit fetal radiation exposure. We report a case of six month pregnant women with critical mitral stenosis suitable for PMV. During introduction of Mullins sheath into innominate vein, little resistance was encountered. We could not exactly ascertain the cause as abdomen shielded was there. Mullins sheath was reintroduced and procedure was completed. At the end sudden hypotension was detected with patient complaining of right hip pain. Venogram showed contrast extravasations from the right common iliac vein confirming iliac vein disruption. Accura balloon was placed across the perforated segment and inflated twice for 4 mints, sealing the perforation. This case shows that immediate treatment with balloon tamponade can result in a successful outcome.
\end{abstract}

Key words: balloon tamponade, mitral stenosis, percutaneous mitral valvotomy, pregnancy, vascular disruption

Folia Cardiologica 2016; 11, 4: 330-333

\section{Introduction}

Mitral stenosis remains the most common type of heart disease in pregnant women in developing countries. Percutaneous mitral valvotomy (PMV) is an effective alternative for the management of such patients. During pregnancy patients with severe MS present a challenging problem because of a high rate of fetal and maternal complications. In pregnant women, some technical problems may be encountered during the procedure. The gravid uterus may compress and distort the inferior vena cava, making passage of catheters difficult. To limit fetal radiation exposure, all patients will have their abdomen shielded with lead sheets from the diaphragm to pubic symphysis.
Active contrast extravasations from a vascular disruption are a life-threatening emergency with high mortality rate. This case shows that when time to diagnose and treat is crucial to the survival of a patient with active hemorrhage and immediate treatment with balloon occlusion can result in a successful outcome.

\section{Case report}

A 19-year-old pregnant woman presented with shortness of breath NYHA class-III in her second trimester. A transthoracic echocardiographic evaluation revealed critical MS with mitral valve area of $0.6 \mathrm{~cm}^{2}$ and no mitral regurgitation. Wilkin's score was 7/16 (2, C1, T2, S2). PMV was planned. 


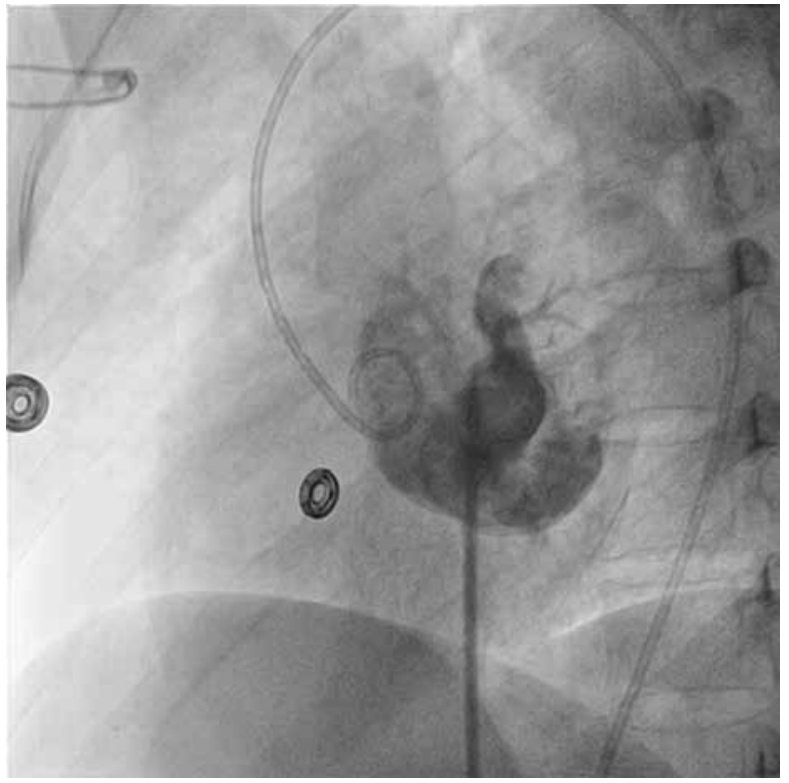

Figure 1. Left atrial angiogram in left anterior oblique $40^{\circ}$ view

Procedural consent was taken. Surgical and gynecology back-up were kept ready. We attached two lead shield sheets together using an adhesive tape to cover the anterior abdomen from diaphragm to pubic symphysis to limit fetal radiation exposure Right femoral artery and venous access was obtained with a $5 \mathrm{~F}$ arterial and $8 \mathrm{~F}$ venous sheaths. A $5 \mathrm{~F}$ pigtail catheter was passed retrograde into the aorta and parked in the noncoronary sinus of the aortic root. A 0.035 " guide wire was then passed up the femoral vein into the IVC and $8 \mathrm{~F}$ Mullins sheath was passed up on the guide wire. Little resistance was encountered and patient also complained of little pain. As abdomen shielded was there we could not exactly ascertain the cause. After little manipulation, Mullins sheath was reintroduced into innominate vein. A curved Brockenbrough septal puncture needle was introduced into the sheath stopping just short of the tip. Septal puncture was done in $\mathrm{LAO} 40^{\circ}$ projection after septal descent and LA was entered and pressure was recorded (Figure 1). The septum was dilated and heparin100 IU/kg was given i.v. Subsequently the Accura balloon (Vascular Concepts, Essex, UK) was introduced and mitral valve dilatation was successfully done. At the end of procedure sudden hypotension was detected with patient complaining of right hip pain. Cardiac tamponade was ruled out. A venogram showed contrast extravagation from the right common iliac vein confirming common iliac vein disruption (Figure 2). Her heparin was reversed with protamine. Then pigtail shaped LA wire was introduced into the right atrium over which Accura balloon catheter was placed across the perforated segment carefully and

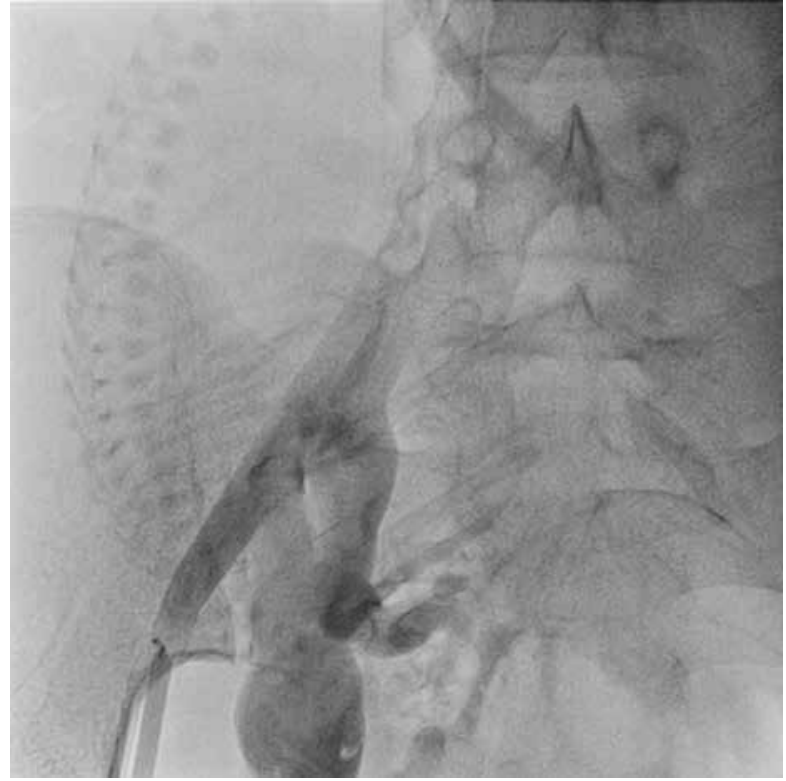

Figure 2. Venogram showing extravasations of contrast material from right common iliac vein (fetal spine also visible on left side)

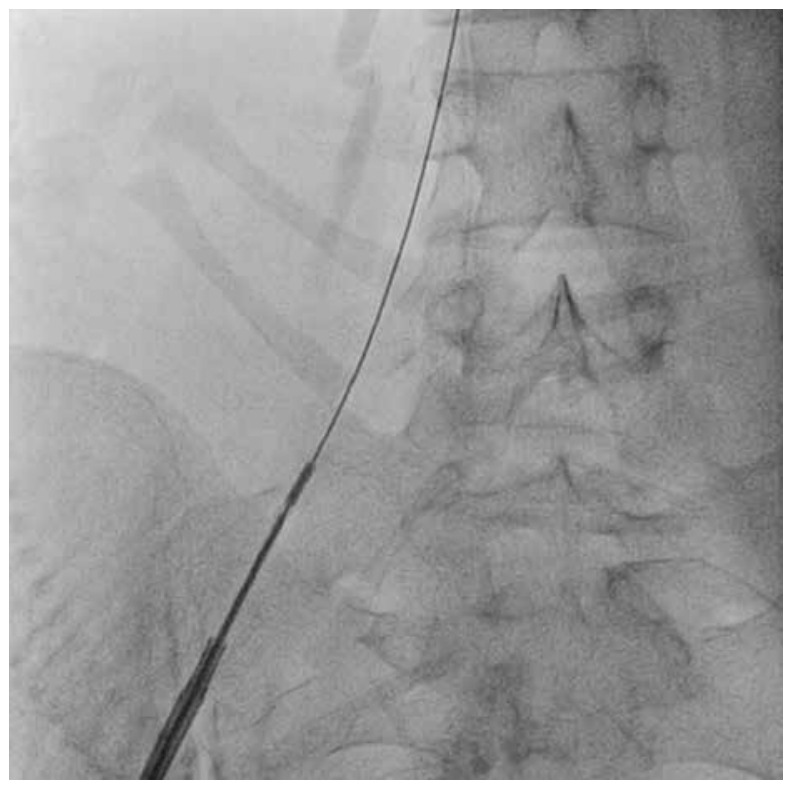

Figure 3. Accura balloon catheter was placed across the perforated segment over the left atrium (LA) wire

inflated for 4 min (Figure 3 and Figure 4). Active contrast extravasations was still persistent though little. Accura balloon was inflated for another 4 min which sealed the perforation (Figure 5). Patient was shifted to ICU and her vitals were closely monitored. She was discharged in stable condition after three days. Three months later she delivered a healthy baby per vaginally. 


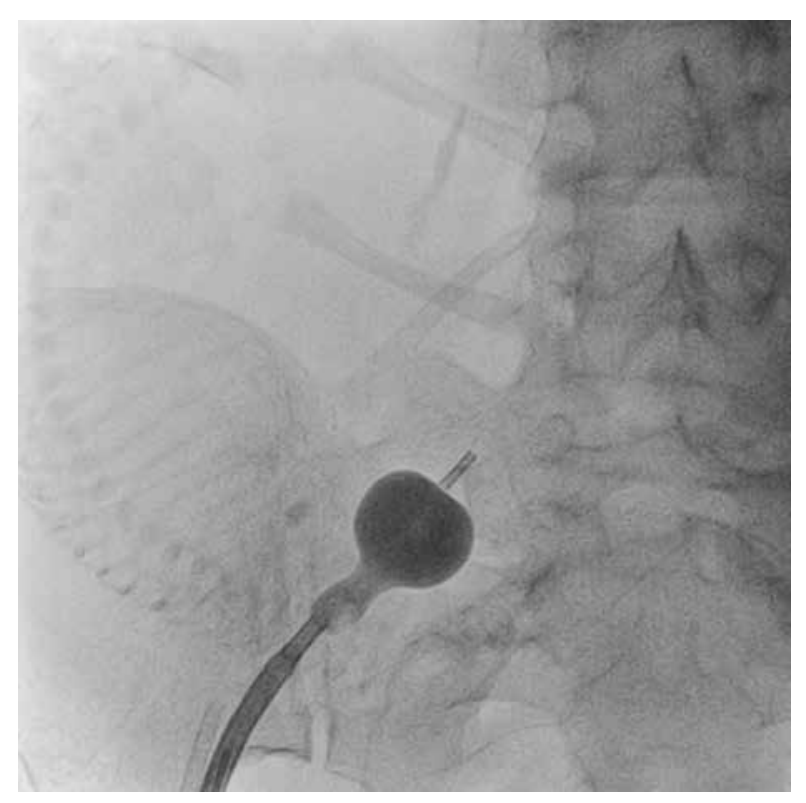

Figure 4. Partially inflated Accura balloon catheter across the perforated segment

\section{Discussion}

Mitral stenosis in pregnancy, if not treated appropriately, is associated with a high maternal and perinatal mortality. PMV is an effective alternative for the management of such patients [1]. During pregnancy patients with severe MS present a challenging problem because of a high rate of fetal and maternal complications [2]. The gravid uterus may compress and distort the inferior vena cava, making passage of catheters difficult and this may be the reason why little resistance was encountered while Mullins sheath was being introduced into innominate vein creating little tear there. Introduction of every hardware should be strictly done under fluoroscopy. As abdomen shielded was there we could not exactly ascertain the cause as this was limiting factor in our case. After little manipulation, Mullins sheath was reintroduced into innominate vein. Since the venous system is a low-flow

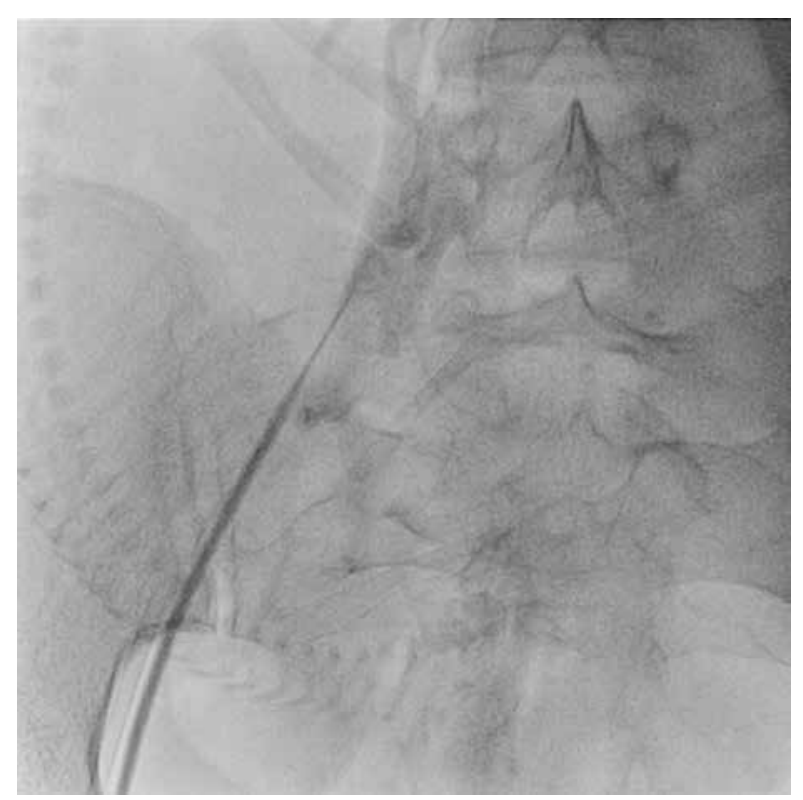

Figure 5. Venogram, after balloon tamponade, showing no extravasations indicating sealed perforation

state, vascular disruption took time to manifest. Active contrast extravasations from vascular disruption are a life-threatening emergency, iliac vein injuries carry up high mortality [3]. Its presence in context with the clinical status of the patient should prompt immediate consideration of percutaneous or surgical intervention to control active hemorrhage [4]. Traditionally, management of common iliac vein injury has involved operative repair in stable patients. In the venous system, covered stent grafts have been limited to use in veno-occlusive disease unlike arterial injuries. Such kind of common iliac vein disruption is exceedingly rare during PMV. This case shows that immediate treatment with balloon occlusion can result in a successful outcome.

\section{Conflict of interest}

The authors declare that there is no conflict of interest. 


\section{Streszczenie}

Przezskórna walwotomia mitralna (PMV) to skuteczna metoda leczenia objawowej stenozy zastawki mitralnej u kobiet w ciąży. W okresie ciąży macica może uciskać i zniekształcać żyłę główną dolną. W celu ograniczenia ekspozycji płodu na promieniowanie u chorych stosuje się osłonę brzuszną w postaci ołowianych ekranów. W niniejszej pracy przedstawiono przypadek kobiety w 6. miesiącu ciąży z krytycznym zwężeniem zastawki mitralnej kwalifikującym się do PMV. W trakcie wprowadzania koszulki Mullinsa do żyły bezimiennej napotkano niewielki opór. Nie można było stwierdzić jego przyczyny ze względu na obecność osłony brzusznej. Powtórnie wprowadzono koszulkę Mullinsa i kontynuowano zabieg. Po zakończeniu zabiegu stwierdzono nagłą hipotensję, a pacjentka skarżyła się na ból w prawej okolicy biodrowej. Na wenogramie widoczny był wyciek kontrastu z żyły biodrowej wspólnej prawej, co potwierdziło rozerwanie naczynia. Balon Accura umieszczono w uszkodzonym segmencie żyły i 2-krotnie napełniono na 4 minuty, uszczelniając perforację. Niniejszy przypadek pokazuje, że szybkie zastosowanie tamponady balonowej pozwala uzyskać pomyślny wynik leczenia.

Słowa kluczowe: tamponada balonowa, stenoza mitralna, przezskórna walwotomia mitralna, ciąża, rozerwanie naczynia

Folia Cardiologica 2016; 11, 4: 330-333

\section{References}

1. Hameed A., Karaalp I.S., Tummala P.P. et al. The effect of valvular heart disease on maternal and fetal outcome of pregnancy. J. Am. Coll. Cardiol. 2001; 37: 893-899.

2. Mcfaul P.B., Dorman J.C., Lamki H. et al. Pregnancy complicated by maternal heart disease; a review of 519 cases. Br. J. Obst. and Gynaec. 1988; 95: 861.
3. Wilson R.F., Wiencek R.G., Balog M. Factor's affecting mortality rate with iliac vein injuries. J. Trauma 1990; 30: 320-323.

4. Federle M.P., Courcoulas A.P., Powell M. et al. Blunt splenic injury in adults: clinical and CT criteria for management with emphasis on active extravasations. Radiology 1998; 206: 137-142. 